\title{
Mixed mesodermal tumor of the corpus uteri with special reference to alkaline phosphatase reactivity:
}

\section{A case report}

Department of Pathology, Gifu University School of Medicine, Gifu, Japan

Kazuo KATO, Masahiko FUJII, Takuji TANAKA, Yasuo BUNAI and Masayoshi TAKAHASHI

Department of Obstetrics and Gynecology, Gifu University School of Medicine, Gifu

Hidehiro TSUKADA

症例は 70 歳の既婚女性で，不正性器出血を訴え子宮全摘をうけた．腫瘍は子宮底に広基性に付 着するポリープ状の軟らかい腫瘍で，外子宮口より突出していた．切除材料の捺印標本にて，腺様 の悪性細胞が単独または集合して多数認められた. 細胞は小型, 類円形で, 辺縁の不鮮明な細胞質 を有していた，核クロマチンは細顆粒状で過染性を示し，カリオン゙ームもみられた．核小体は著明 に腫大し通常 1 個みられた. 子宮内膜の高分化型腺癌に類似していた. 同時に繊細なクロマチンと 腫大した核小体を有する卵円形の核と cyanophilic に淡く染をる胞体からなる紡鍾形ないし多形 性の細胞が単独あるいは数個の集団として認められた．これらは未分化な内膜閒質細胞肉腫の細胞 に類似していた．組織標本で認められた軟骨組織や類骨組織は捺印標本には認められなかった．細 胞化学的に, アルカリホスファターゼ活性は細胞により差異が強く, 腺様の悪性細胞は細胞辺縁を 中心に強、活性を呈したが, 大型多形性の肉腫様細胞では活性を認めなかった. アルカリホスファ ターゼ染色は本例のような混合性腫隚において，上皮性成分と非上皮性成分の鑑別に有用なことが 示唆された.

Key words : Uterus_-Mixed mesodermal tumor-Cytochemistry — Alkaline phosphatase

Mixed mesodermal tumor of the corpus uteri with special reference to alkaline phosphatase reactivity: A case report

Kazuo KATO, M.D., Masahiko FUJII, M.D., Takuji TANAKA, M.D., Yasuo BUNAI, M.D. and Masayoshi TAKAHASHI, M.D., F.I.A.C.

Department of Pathology, Gifu University School of Medicine, Gifu, Japan

Hidehiro TSUKADA, M.D.

Department of Obstetrics and Gynecology, Gifu University School of Medicine, Gifu

論文別刷請求先 ⿶500 岐阜市司町 40 岐阜大学医学部病理 学第 1

昭和 57 年 6 月 21 日受付

\section{Introduction}

The mixed mesodermal tumor of the corpus uteri is a rare malignant neoplasm composed of epithelial and mesenchymal tissues, occasionally containing primitive striated muscle, cartilaginous or osteoid elements which are heterotopic to the uterus.

Ober et al. separated the mixed Müllerian tumor into mixed homologous and mixed heterologous sarcoma, depending upon the absence or presence of 
heterotopic tissue ${ }^{12)}$. These two types of tumor are described respectively by the terms " carcinosarcoma" and "mixed mesodermal tumor" 4,15$)$.

This paper reports a case of mixed mesodermal tumor with cytochemical findings.

\section{Materials and Methods}

Imprinted smears and histological materials were obtained from the cut surface of the fresh tumor which was surgically removed. The Papanicolaou stain and cytochemical studies described below were made on the imprinted smears. Pieces of tissue were quickly frozen in liquid nitrogen and were cut to a thickness of 10 microns in a cryostat at $-20^{\circ} \mathrm{C}$ for the histochemical study described below. Another specimens were fixed in 10\% formalin and embedded in paraffin for the periodic acid-Shiff reaction and Mallory's phosphotungstic hematoxylin stain, in addition to conventional hematoxylin and eosin stain.

Alkaline phosphatase staining: The naphthol ASBI phosphate azo dye method after Burstone was tried on the imprinted smears and frozen sections ${ }^{3)}$. They were incubated at $37^{\circ} \mathrm{C}$ for $30 \mathrm{~min}$. in a solution containing $0.005 \%$ naphthol AS-BI phosphate dissolved in 0.05 M 2-amino-2-methyl-1, 3-propanediol buffer ( $\mathrm{pH}$ 9.8). Immediately before use, $5 \mathrm{mg}$ of Fast blue RR salt was added to $10 \mathrm{ml}$ of the mixture.

\section{Case report}

A 70-year-old tetragravida woman sought medical care in October 1979 because of irregular genital bleeding for 6 months. On the basis of curreted materials, the initial diagnosis was adenocarcinoma of the endometrium. Two months following the curet. tage she underwent total abdominal hysterectomy with bilateral adnectomia. At the time of surgery the tumor was found in the enlarged uterus and visibly protruded from the cervix, but it did not extend beyond the uterine wall. Although she has received neither postoperative radiation nor chemotherapy, the patient's condition has remained essentially uneventful up to the present time three years

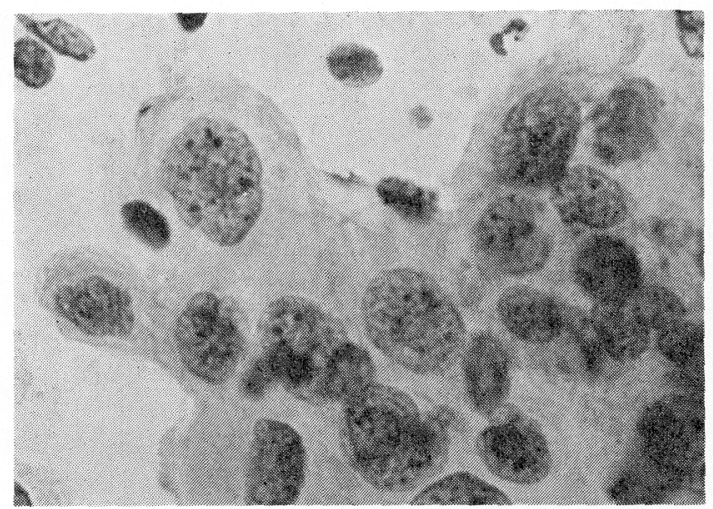

Fig. 1 Cancer cells with hyperchromatic nuclei varying in size, and the delicate, finely vacuolated cytoplasm. (Pap., $\times 280$ )

after surgery.

\section{Pathological findings}

Gross appearance: The tumor was located in the fundus uteri. It was a solitary, polypoid, soft mass, attached to the myometrium with a broad base. The mass filled the endometrial cavity and protruded downward from the external os of the uterus. There were areas of necrosis and hemorrhage in the tumor.

Cytological features: We found atypical and malignant glandular epithelial cells the most common components on imprint smears. Those cells were small and mostly round (Fig, 1), and arranged mostly in aggregates. Their cytoplasms were more substantial than a scant rim. Their chromatins were either finely stippled or coarsely granular. Their nucleoli were discernible and prominent. They showed a striking resemblance to tumor cells of well-differentiated adenocarcinoma of the endometrium.

Anaplastic malignant cells which could not be classified cytologically as either glandular or epidermoid cells were not uncommon (Fig. 2). These small anaplastic cells in loose clusters and sheets appeared to be neoplastic stromal cells rather than malignant epithelial cells.

Malignant mesenchymal cells were seen singly or in loose clusters (Figs. 2 4). They were large monoor multinucleated cells with ill-defined, elongated or large polymorphic cytoplasm. The cytoplasm was cyanophilic with Papanicolaou stain and blended in- 


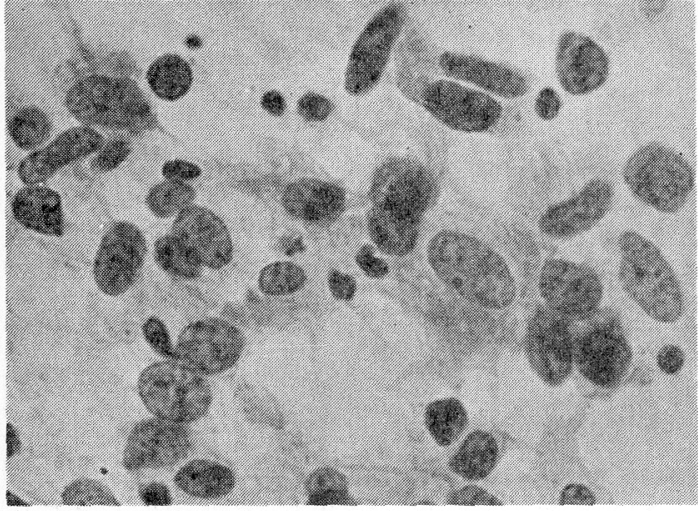

Fig. 2 Cluster of malignant cells of variable sizes, some with elongated cytoplasms, presumably reflecting the sarcomatous component of the tumor. (Pap., $\times 280)$

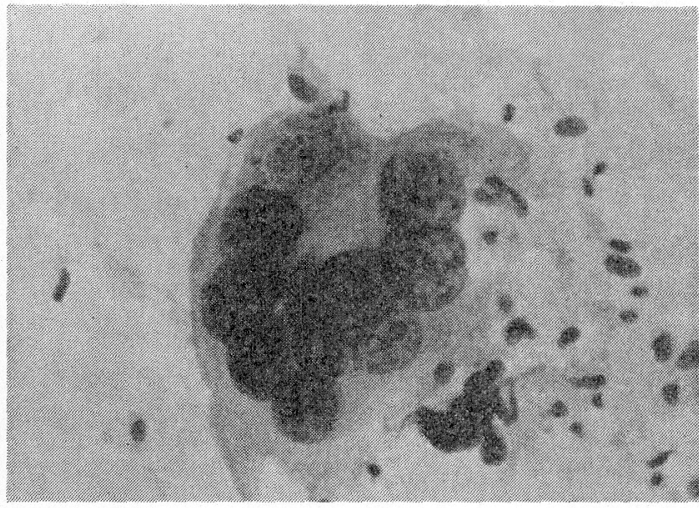

Fig. 4 A large and multinucleated cell. (Pap., $\times 280)$

timately into the background of the smear with indefinite contours. Most of the nuclei were oval rather than round and had finely granular nuclear chromatin, a distinct nuclear membrane, and one or more prominent nucleoli. However, the nuclei ranged from clear vesicular to hyperchromatic, densely granular forms. Undifferentiated spindle cell sarcomas and endometrial stromal sarcomas seemed to be the basic mesenchymal elements in this case.

\section{Cytochemical findings}

PAS staining: Although most cells did not show positive activities, some small and round cells in clusters did (Fig. 5).

Alkaline phosphatase staining: There were various degrees of activities among glandular-like cells, but most of the large, anaplastic cells and the

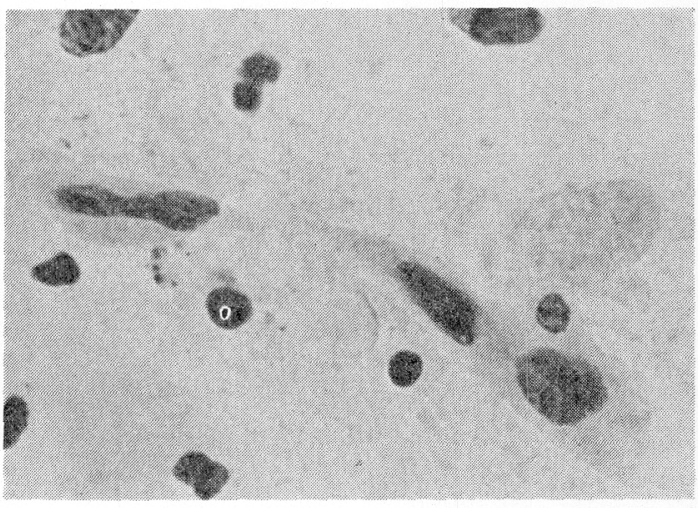

Fig. 3 An anaplastic and hyperchromatic spindle cell with an indistinct cell border. (Pap., $\times 280$ )

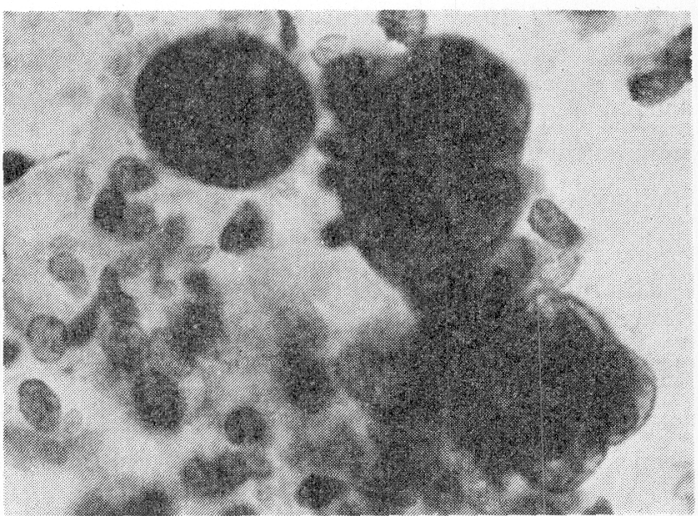

Fig. 5 Several cells in cluster are stained PAS positive. (PAS, $\times 280)$

multinucleated cells were not stained positively. Small, round cells in clusters showed high alkaline phosphatase activity (Fig. 6). Some cells which had elongated cytoplasm and oval nuclei showed higher activity in the free edges of cytoplasm against nuclei. The highest activity was noticed in the peripheral areas of glandular clusters with small, round cells.

\section{Histological features}

The tumor was characterized by the admixture of neoplastic epithelia and sarcomatous stroma (Fig. 7). The sarcomatous element was either immediately adjacent to glands or in transition to carcinomatous patterns. The epithelial component was adenocarcinomatous, with glandular lumens lined by low to high columnar cells. The mesenchymal areas were composed of hyperchromatic, oval to spindle-shaped cells, 


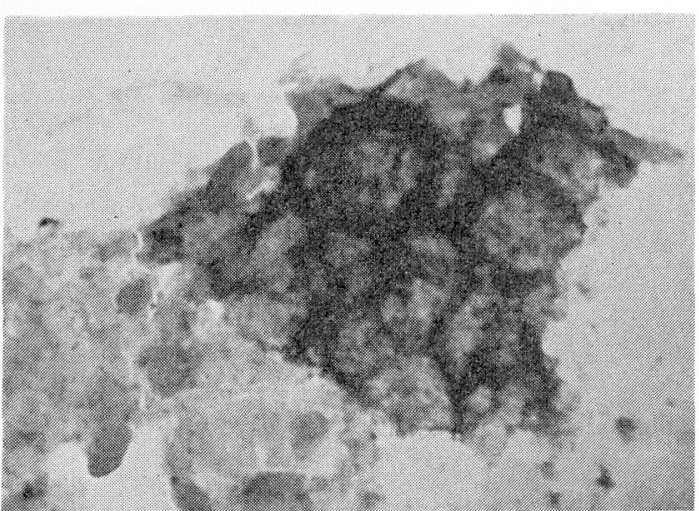

Fig. 6 Cluster of cells with high alkaline phosphatase activity. (Alkaline phosphatase staining, $\times 280$ )

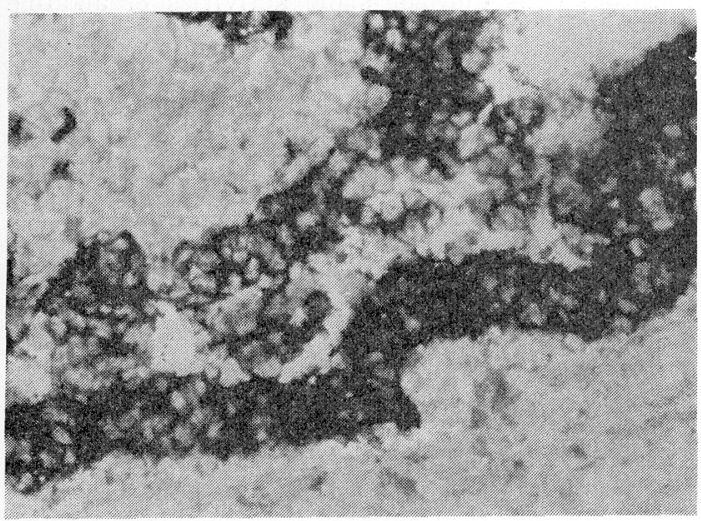

Fig. 8 High activities of alkaline phosphatase shown in the carcinomatous cells. (Alkaline phosphatase staining, $\times 140$ )

in which mitotic figures were frequent. Loose, myxomatous mesenchymal cells appeared more commonly than a dense aggregate of such cells. Poorly organized osteoid occurred in highly cellular and pleomorphic areas with numerous mitotic figures. The cartilage was merged into the sarcomatous matrix of the tumor. Some areas were extremely pleomorphic in appearance, yet rhabdomyomatous cross striation could not be found in this case despite the use of Mallory's phosphotungstic acid hematoxylin stain.

Histochemically the epithelial cells were sometimes stained PAS positive and showed intense alkaline phosphatase activity (Fig. 8), but stromal cells showed neither such activity nor PAS reactivity.

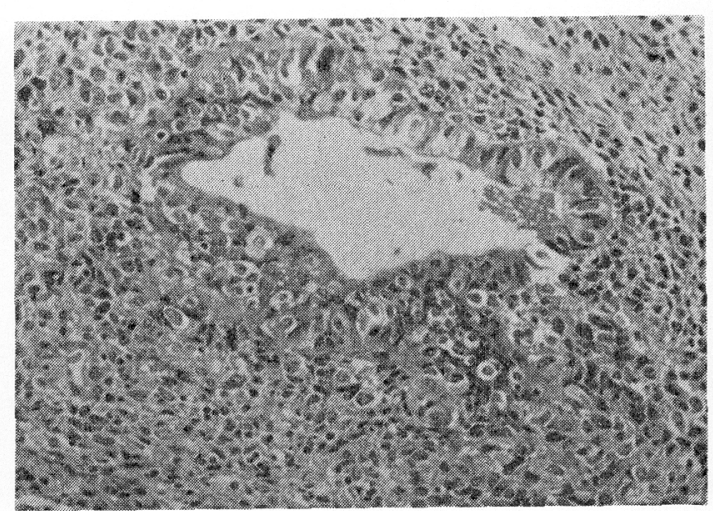

Fig. 7 A carcinosarcomatous pattern consisting of glandular and stromal components comprising large areas of the tumor. $(\mathrm{H}-\mathrm{E}, \times 70)$

\section{Discussion}

Malignant mixed Müllerian tumor is the preferred term for those uterine neoplasms that contain both sarcomatous and carcinomatous elements. The lesions are subclassified as follows: 1) carcinosarcoma that is homologous, as if the sarcomatous elements resembled mesenchymal tissue normally present in the uterus, i.e., endometrial stroma and smooth muscle, and 2) mixed mesodermal tumor that is hetelogous, as if these elements were differentiated into malignant mesenchymal tissue foreign to the uterus, for example, osteosarcoma, chondrosarcoma or rhabdomyosarcoma ${ }^{12,13)}$. The distinction between the two tumor groups was based only on the presence or absence of heterotopic elements, the recognition of which may be quite arbitrary and depends upon many variable factors. Norris et al. found the presence of cartilage within mixed mesodermal tumors indicated a favourable prognosis, whereas there are no survivors in cases of tumors that contained rhabdomyoblast ${ }^{11)}$. Chuang et al. and others have reported that the type of heterotopic tissue does not influence prognosis, only tumor spread at the time of diagnosis being important $t^{1,4,10,13,15)}$. In this case, tumor only spread to the uterine wall and had no striated rhabdomyoblasts, so her condition has remained uneventful up to the present time three years after surgery, although the patient has received surgery alone. 
In this case several components such as cartilage and osteoid were recognized histologically, though they were unrecognizable on imprint smears. Boram et al. have reported that a cytologically characteristic picture which might definitely be diagnostic of a mesodermal mixed tumor has rarely been encountered, except for occasional reports in which malignant spindle cells with striations, in combination with malignant glandular epithelial cells, were discernible ${ }^{2,7,14)}$. Negative cytological diagnosis was reported in about 10 to $45 \%$ of the cases in which cy. tological smears were obtained.

It appears likely that mixed Müllerian tumors arise from a neoplastic cell individually having the capacity to form both glands and stroma (multipotent cells), because the mixed Müllerian tumors arise within the endometrium, and endometrial stromal cells have the capacity to produce both glands and stroma. Other support for the origin of these tumors from multipotential cells has been provided by tissue culture of a mixed mesodermal tumor that grew out of a single cell strain. When neoplastic cells once differentiated and gained a fixed potency during their proliferation, some were able to form only glands and others to form only mesenchymal tissue. This has been supported by another tissue culture of a carcinosarcoma that grew from two cell types, one type resembling carcinoma, the other sarcoma ${ }^{9}$. Carcinomatous cells with atypical spindle shapedcells forming sarcoma-like areas may be difficult or impossible to separate from sarcomatous cells. There is no infallible criterion for separating carcinomas from sarcomas, and certain carcinomas may be able to evolve into sarcoma. In this cytochemical study, the carcinomatous cells appeared to be distinguished from sarcomatous cells by their high intensity of alkaline phosphatase activity, which in this case showed the same intensity of activity as cells in a case of endometrial carcinoma. This suggests that alkaline phosphatase staining could be a useful method for diagnosis of such tumors as carcinosarcoma in smears.

\begin{abstract}
Histochemical staining for alkaline phosphatase was applied to cytological specimens from a mixed mesodermal tumor of the corpus uteri, for the aid of morphological diagnosis of cytology.

In cytological and histological findings, the main tumor consisted of endometrial carcinoma-like cells and sarcomatous cells. Cartilaginous tissue and osteoid-like elements were observed histologically, but those elements were not recognized on imprinted materials. Cytochemically, carcinomatous cells had high activities of alkaline phosphatase but sarcomatous cells did not show activities of alkaline phosphatase.

It is convenient to diagnose epithelial cells and mesenchymal cells on imprinted materials by staining for alkaline phosphatase.
\end{abstract}

\section{References}

1) Aaro, L.A., Symmonds, R.E. and Dockerty, M.B. : Sarcoma of the uterus, Am. J. Obstet. Gynecol., $94: 101 \sim 109,1966$.

2) Boram, L.H., Erlandson, R.A. and Hajdu, S.I. : Mesodermal mixed tumor of the uterus, Cancer, $30: 1295 \sim 1306,1972$.

3) Burstone, M.S. : Histochemical demonstration of phosphatases in frozen sections with naphthol-ASphosphates, J. Histochem. Cytochem., $9:$ 146 153, 1961.

4) Chuang, J.T., Van Velden, D.J.J. and Graham, J. B. : Carcinosarcoma and mixed mesodermal tumor of the uterine corpus, Obstet. Gynecol., $35: 769 \sim$ $780,1970$.

5) Fenn, M.E. and Abell, M.R. : Carcinosarcoma of the ovary, Am. J. Obstet. Gynecol., $10: 1066 \sim 1074$, 1971.

6) Hall-Craggs, M., Toker, C. and Nedwich, A.: Carcinosarcoma of the uterine cervix, Cancer, 48 : $161 \sim 169,1981$.

7) Hayes, D. : Mixed Müllerian tumor of the corpus uteri, Obstet. Gynecol. Brit. Commonwealth, 81 : 160 164, 1974.

8) Hoeffken, H., Rummel, H.H., Heberling, D., Leppien, G. and Hoppe, L. : Korrelation zytologischer 
und histologischer Befunde bei uterinen Sarcomen, Gewurtsh. Frauenheilk., $40: 791 \sim 797,1980$.

9) Ishiwata, I., Ishiwata, C., Nagayama, T. and Isikawa, H. : Histogenesis and culture of human uterine carcinosarcoma, Cancer Res., $41: 1978 \sim 1983$, 1981.

10) Mitchard, P.J., Swingler, G.R. and Cave, D.G. : Cytologic features of a mixed mesodermal tumor of the uterus demonstrated by cells obtained with the Mi-Mark endometrial sampler, Acta Cytol., $24: 363 \sim 365,1980$.

11) Norris, H.J. and Taylor, H.B. : Mesenchymal tumors of the uterus-III. A clinical and pathologic study of the carcinosarcomas, Cancer, 19 :
1459 1465, 1966.

12) Ober, W.B. and Tovell, H.M.M. : Mesenchymal sarcomas of the uterus, Am. J. Obstet. Gynecol., $77: 246 \sim 268,1959$.

13) Taylor, C.W. : Müllerian mixed tumor, Acta Path. Microbiol. Scand., Section A, 80 Suppl., : 48 55, 1972.

14) Vellios, F., Stander, R.W. and Huber, C.P. : Carcinosarcoma (malignant mesodermal tumor) of the uterus, Am. J. Clin. Pathol., 39 : 496 505, 1963.

15) Williamson, E.O. and Christopherson, W.M. : Malignant mixed Müllerian tumors of the uterus, Cancer, $29: 585 \sim 592,1972$. 